\title{
INFLUENCE OF OCCLUSAL LOADING LOCATION ON THE STRAIN DEVELOPED AROUND IMPLANTS WITH TWO DIFFERENT CREST MODULE DESIGNS (IN VITRO STUDY)
}

\author{
Marwan A. Aggag ${ }^{1} B D S$, Yousreya A. Shalaby ${ }^{2} h D$, Mohammed S. Nassif ${ }^{3} P h D$,
}

\author{
Amir S. Azer ${ }^{4} P h D$
}

\begin{abstract}
INTRODUCTION: Mechanical overload is thought to be one of the major causes of implant complications. The addition of micro threads increase linear length of coronal implant surface available for biologic width and allows some stress transfer and relieve the crestal stress and strain concentration in the coronal region.

OBJECTIVES: Was to compare the influence of occlusal loading location on the strain developed around implants with two different crest module designs.

MATERIALS AND METHODS: Ten Polyurethane test blocks in which implants were fixed at the maxillary left first premolar area. Specimens were divided into two parallel groups $(n=5)$, Group (I) -implants, with micro threads, Group (II) implants with wide-groove threads. Strain gauges were connected to a strain meter to record the developed strain. A universal testing machine was used for load application up to $100 \mathrm{~N}$. The data were statistically analyzed $(\mathrm{p} \leq 0.05)$.

RESULTS: Group I exhibited the lower mean micro-strain values $(260.0 \pm 192.6 \mu \varepsilon)$ than Group II $(513.2 \pm 108.2 \mu \varepsilon)$.There was statistically significant difference between both groups $(\mathrm{p}>0.05)$.

CONCLUSIONS: Crest module designs affected the stress pattern induced around dental implants.

KEYWORDS: Implant, Crest module, Micro threads, Macro threads, Strain gauge.

1. Instructor at Fixed Prosthodontics Department, Faculty of Dentistry, Pharos University in Alexandria, Egypt.

2. Professor of Fixed Prosthodontics, Department of Conservative Dentistry, Faculty of Dentistry, Alexandria University, Egypt.

3. Associate Professor of Dental Biomaterials, Department of Dental Biomaterials, Faculty of Dentistry, Ain Shams University, Egypt.

4. Lecturer of Fixed Prosthodontics, Department of Conservative Dentistry, Faculty of Dentistry, Alexandria University, Egypt.
\end{abstract}

\section{INTRODUCTION}

The use of dental implants for oral rehabilitation of either total or partial edentulous arches has been applied to replace lost teeth, depending on the alveolar bone (1). In fixed prosthesis rehabilitation, the occlusal forces are directly applied onto the prosthesis and transmitted to the bone/implant interface and the maintenance of the periimplantar bone tissue should be the primordial fact to achieve long-term treatment success (2).

The longevity of the implants relies primarily on their stability at placement. However, early peri-implant bone loss has been observed in many implant systems and after different surgical approaches (3). In particular, crestal bone loss is the leading symptom of implant failure after osseointegration and the achievement of primary stability. The majority of crestal bone loss occurs during the first year of implant function, and it can be as much as $1.2 \mathrm{~mm}$ corono-apically (4).

The presence of crestal bone is one of the key factors that influences the appearance or maintenance of peri-implant soft tissue architecture. There are many suggested causes for early implant bone loss, two of them being occlusal overload and implant crest module (5). The crest module of the implant body refers to the transosteal region of the implant that receives the stress from the implant after loading (6).

An example of a suspected bone morphology alteration due to stress is the apical migration of crestal bone down to the first thread of many implant systems (7).
It has also been hypothesized that the bone loss may slow down at the first thread when the force changes from crest shear force to the compressive force induced by the thread itself. In general, a functional implant may encounter many different forces, such as rotation, shear, and compression. It was found that the cortical bone layer withstands compressive force the best (8).

Various dental implants with different surface designs are being used for dental rehabilitation of patients. Design of the implant crest module (or collar) can influence bone loss. Many of them are two-stage, submerged implants with a $2 \mathrm{~mm}$ smooth coronal collar/crest module design. Bone loss with smooth collar has been observed (9). It has been observed that implants having a rough/ coated collar design show reduced crestal bone loss (10).

Traditionally, the cervical or "neck" region of dental implants had a non-threaded, highly polished surface of sufficient height to accommodate biologic width without exposing much of the threaded implant segment meant to maintain implant fixation. Polished collar heights were generally in the range of 0.75 to $2.8 \mathrm{~mm}$. Remembering that establishment of biologic width required at least $1.5 \mathrm{~mm}$ of linear implant surface from the micro-gap, polished collar height became more important with rough and moderately rough implant surfaces which ideally should remain buried in bone to avoid complications like peri-implantitis (11). Naturally, use of platform-switching to add a horizontal component to 
biologic width allows shorter polished collar regions to be used successfully.

However, another effective way to manage the implant collar segment is to add micro-threads to its geometry. Micro-threads offer two possible advantages. Firstly, their addition increases linear length of coronal implant surface available for biologic width and allows some stress transfer in the coronal region superior to the macro-threaded segment of implant body (12). This lower level of stress transfer to crestal bone is less likely to cause bone micro-fractures and reduces the probability for stressshielding and disuse atrophy of crestal bone as may occur with traditional polished implant collars. Few implant designs incorporate micro-threads. Rather, there has been a move to shorten or eliminate polished collar segments, with manufacturers electing to have implant collars with moderately rough surfaces in the hope of stimulating crestal bone with low levels of stress transfer as is thought to occur with micro-threads (13).

A second design strategy in implant systems is a switched platform abutment on an implant fixture. In essence, platform switching is the placement of a smallerdiameter abutment relative to the platform of the fixture. Primarily associated with the internalization of the microgap (5), this design has also been suggested as beneficial for crestal bone preservation (14).

The strain gauge technique has been used to evaluate stresses in implant supported prosthesis both in vitro $(15,16)$ and in vivo $(17,18)$. Some failures of the implant system have been associated with occlusal overload as the primary factor (19).

This study was attempted to compare the influence of occlusal loading location on the strain developed around implants with two different crest module designs.

The null hypothesis for this study was: implants with micro threads crest module design have a favorable effect on the stress distribution when compared to implants with wide-groove threads crest module design.

\section{MATERIALS AND METHODS}

Solid Rigid Polyurethane Test Blocks (Aptic Medical, Washington, USA) were used as an alternative test medium for human bone. The uniformity and consistent properties of rigid polyurethane foam for comparative testing blocks are $5 \mathrm{~cm} \times 12.5 \mathrm{~cm}$ x $4.5 \mathrm{~cm}$.

The blocks were sawed using electric saw. Ten blocks were obtained, $2 \mathrm{~cm}$ length $5 \mathrm{~cm}$ width and $4.5 \mathrm{~cm}$ height dimensions (20).

A patient's diagnostic cast having missing maxillary left first premolar, the intact inter-abutment distance of the edentulous space of $8 \mathrm{~mm}$ was scanned using 3D scanner (Copenhagen, Denmark). Special software Magics software (version 8, Leuven, Belgium) was used to section the model from maxillary left canine to the maxillary left second premolar.

Then the sectioned part was redesigned and both teeth were connected with a connector from their palatal surfaces to standardize the $8 \mathrm{~mm}$ edentulous space in all the test blocks. Then the final design was printed out using special 3D Dental printer (EnvisionTEC, Germany) with specific material (E-Denstone) that was fixed on the polyurethane test blocks using cyanoacrylate adhesive.
The blocks were scanned by Cone beam computed tomography (CBCT) (J.Morita,California, USA) and with the use of software program a surgical stent with titanium sleeve will be printed out using the special 3D Printer, One surgical guide will be fabricated from specific material (EShell ${ }^{\circledR}$ 600).

Blocks were randomly divided into two main groups five blocks each according to the implant design used and accordingly the fabricated crowns.

Group I: Crown restorations supported on $4.1 \mathrm{~mm}$ dental implants diameter with micro threads design.

Group II: Crown restorations supported on $4.1 \mathrm{~mm}$ dental implants diameter with wide-groove threads design.

For Group I: The stent was placed on the polyurethane block and through the titanium sleeve; a hole was drilled for implant installation. 5 dental implants of $4.1 \mathrm{~mm}$ diameter $12 \mathrm{~mm}$ length with micro threads were fixed in the 5 Polyurethane Test Blocks. 5 Titanium straight abutments of $4.5 \mathrm{~mm}$ diameter were tightened with the corresponding abutment screws according to the manufacturer's instructions with a calibrated torque driver. For Group II: The stent was placed on the polyurethane block and through the titanium sleeve; a hole was drilled for implant installation. 5 dental implants of $4.1 \mathrm{~mm}$ diameter $12 \mathrm{~mm}$ length with wide-groove threads were fixed in the 5 Polyurethane Test Blocks. 5 Titanium straight abutments of $4.5 \mathrm{~mm}$ diameter were tightened with the corresponding abutment screws according to the manufacturer's instructions with a calibrated torque driver. Full contoured wax-ups of the maxillary first premolar crowns were fabricated using Sirona inLab CAD-CAM system to standardize the mesio-distal and bucco-lingual widths of the fabricated wax patterns then were sprued, invested, casted, finished and polished according to the manufacturer's instructions. Then crowns were individually adapted and cemented to the corresponded abutments at the blocks using glass ionomer luting cement (Medicem, Germany).

Four strain gauges (CC-33, EP-34strain gauge) were fixed for each implant buccally, palataly, mesially and distally on the model adjacent to the implant site. Strain gauges were bonded to the selected sites using Cyanoacrylate adhesive. Then were connected to a strain meter (Kyowa sensor interface PCD-300A, Kyowa Electronic Instrument Co.Japan) to record the developed strain. A universal testing machine was used for load application at four points: the central fossa of the crown, the buccolingual midpoint of the mesial and distal marginal ridges and oblique ( $45^{\circ}$ inclined) load. Figure $(1,2)$.

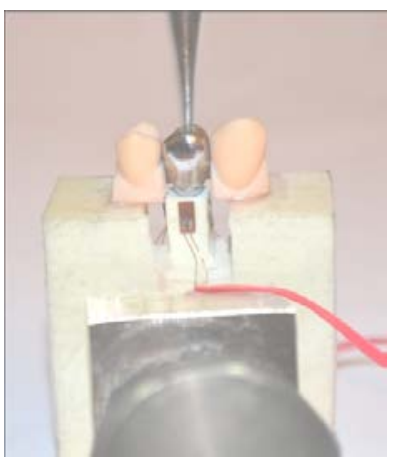

Fig. (1): Showing vertical load application. 


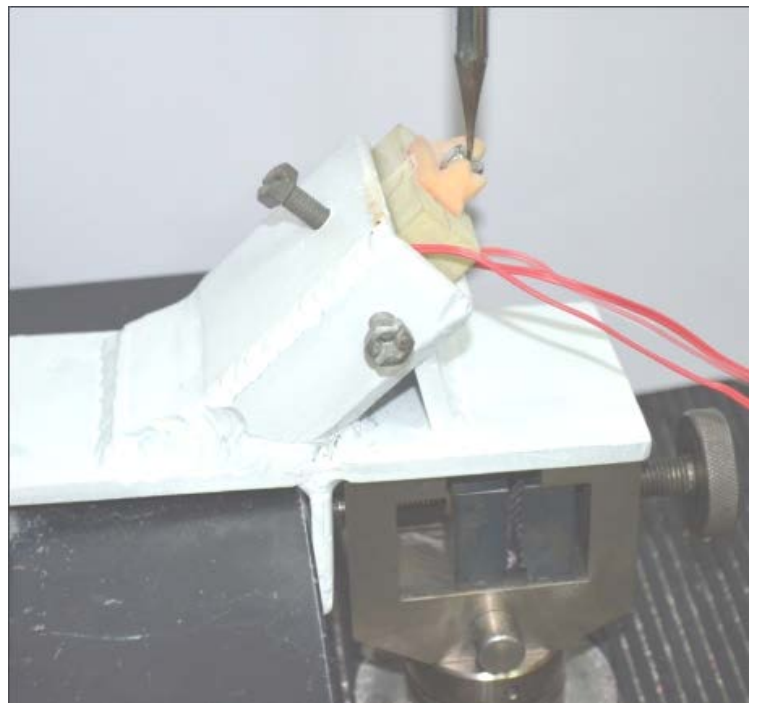

Fig. (2): Showing oblique load application.
Table 1: Comparison of total micro-strain values of same loading sites of the two different implants studied groups

\begin{tabular}{|c|c|c|c|c|c|c|c|c|c|}
\hline \multirow{3}{*}{$\begin{array}{c}\text { Loadi } \\
\text { ng Site }\end{array}$} & \multicolumn{8}{|c|}{ Implant } & \multirow{3}{*}{ t (P) } \\
\hline & \multicolumn{4}{|c|}{ Group I } & \multicolumn{4}{|c|}{ Group II } & \\
\hline & $\begin{array}{c}\text { Mini } \\
\mathbf{m u} \\
\mathbf{m}\end{array}$ & $\begin{array}{l}\text { Maxi } \\
\text { mum }\end{array}$ & $\begin{array}{c}\text { M } \\
\text { ea } \\
\mathbf{n}\end{array}$ & SD & $\begin{array}{c}\text { Mini } \\
\mathbf{m u} \\
\mathbf{m}\end{array}$ & $\begin{array}{l}\text { Maxi } \\
\text { mum }\end{array}$ & $\begin{array}{c}\text { M } \\
\text { ea } \\
\mathbf{n} \\
\end{array}$ & $\begin{array}{l}\text { S } \\
\text { D }\end{array}$ & \\
\hline $\begin{array}{c}\text { Centr } \\
\text { al } \\
\text { fossa }\end{array}$ & $\begin{array}{c}162 . \\
5\end{array}$ & 402.5 & $\begin{array}{l}28 \\
4.0\end{array}$ & $\begin{array}{l}11 \\
2.8\end{array}$ & $\begin{array}{c}397 . \\
5\end{array}$ & 532.5 & $\begin{array}{c}48 \\
4 . \\
5\end{array}$ & $\begin{array}{l}5 \\
2 . \\
1\end{array}$ & $\begin{array}{c}3.1 \\
(0.007) \\
*\end{array}$ \\
\hline $\begin{array}{c}\text { Mesial } \\
\text { M.R. }\end{array}$ & $\begin{array}{c}125 . \\
0\end{array}$ & 430.0 & $\begin{array}{c}24 \\
5.5 \\
0\end{array}$ & $\begin{array}{c}12 \\
5.7 \\
5\end{array}$ & $\begin{array}{c}377 . \\
5\end{array}$ & $\begin{array}{c}1065 . \\
0\end{array}$ & $\begin{array}{l}61 \\
1 . \\
5\end{array}$ & $\begin{array}{r}2 \\
9 \\
8 . \\
3\end{array}$ & $\begin{array}{c}2.528 \\
(0.049) \\
*\end{array}$ \\
\hline $\begin{array}{c}\text { Distal } \\
\text { M.R. }\end{array}$ & $\begin{array}{c}127 . \\
5\end{array}$ & 385.0 & $\begin{array}{l}25 \\
0.5\end{array}$ & $\begin{array}{l}10 \\
6.4\end{array}$ & $\begin{array}{c}345 . \\
0\end{array}$ & 667.5 & $\begin{array}{c}44 \\
3 . \\
5\end{array}$ & $\begin{array}{l}1 \\
3 \\
7 . \\
8\end{array}$ & $\begin{array}{c}2.5 \\
(0.038) \\
*\end{array}$ \\
\hline $\begin{array}{c}\text { Obliq } \\
\text { ue }\end{array}$ & $\begin{array}{c}1997 \\
.5\end{array}$ & $\begin{array}{c}4247 . \\
5\end{array}$ & $\begin{array}{c}33 \\
59 . \\
0\end{array}$ & $\begin{array}{l}95 \\
9.4\end{array}$ & $\begin{array}{c}3342 \\
.5\end{array}$ & $\begin{array}{c}5530 . \\
0\end{array}$ & $\begin{array}{l}45 \\
52\end{array}$ & $\begin{array}{l}8 \\
5 \\
8 . \\
0\end{array}$ & $\begin{array}{c}2.1 \\
(0.072)\end{array}$ \\
\hline
\end{tabular}

$\mathrm{t}$ : independent samples t-test

$* \mathrm{P} \leq 0.05$ (significant)

\section{Statistical analysis:}

Data were fed to the computer and analyzed using IBM SPSS software package version 20.0 (21). Quantitative data were described using range (minimum and maximum), mean, standard deviation and median. The distributions of quantitative variables were tested for normality. Significance of the obtained results was judged at the $5 \%$ level.

The used tests were

\section{1 - Student t-test}

For normally quantitative variables, to compare between two studied groups

\section{2 - F-test (ANOVA)}

For normally quantitative variables, to compare between more than two studied groups.

\section{RESULTS}

By using One Way ANOVA for statistical analysis of micro-strain values of different loading sites within Group I and Group II.

Group I: (Implants with micro threads crest module design): Table (1) and Figure (3) showed that:

The highest mean micro-strain value was recorded in oblique load $(3359.0 \pm 959.4 \mu \varepsilon)$, followed by central fossa load $(284.0 \pm 112.8 \mu \varepsilon)$, then distal load $(250.5 \pm$ $106.4 \mu \varepsilon$ ), and the lowest micro-strain value was recorded in mesial load $(245.5 \pm 125.75 \mu \varepsilon)$.

On comparing between vertical loading and the oblique load $\left(45^{\circ}\right)$ inclination applied within Group I at (central fossa, mesial and distal). It showed that oblique load provided higher micro-strain value than the vertical loading applied. Therefore, oblique load revealed statistically significant effect on the micro-strain values of the loading sites $(\mathrm{p} \leq 0.05)$.

Group II: (Implants with wide-groove threads crest module design): Table (1) and Figure (3) showed that:

The highest mean micro-strain value was recorded in oblique load $(4552.0 \pm 858.0 \mu \varepsilon)$, followed by mesial load $(611.5 \pm 298.3 \mu \varepsilon)$, then central fossa load $(484.5 \pm 52.1$ $\mu \varepsilon)$, and the lowest micro-strain value was recorded in distal load $(443.5 \pm 137.8 \mu \varepsilon)$.

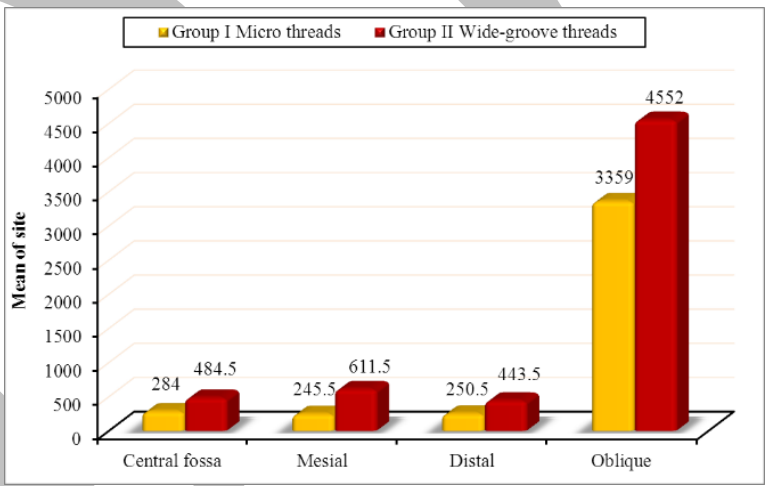

Fig. (3): Comparison of total micro-strain values of same loading sites of the two different implants studied groups

On comparing between vertical loading and the oblique load $\left(45^{\circ}\right)$ inclination applied within Group II at (central fossa, mesial and distal). It showed that oblique load provided higher micro-strain value than the vertical loading applied. Therefore, oblique load revealed statistically significant effect on the micro-strain values of the loading sites $(\mathrm{p} \leq 0.05)$.

Student t-test for statistical analysis was used for comparing same loading sites of the two different implants studied groups, in Table (1) and Figure (3) showed that:

\section{a- At the central fossa loading:}

For group I: total buccal, palatal, mesial and distal mean micro-strain value was $284 \pm 112.8 \mu \varepsilon$.

For group II: total buccal, palatal, mesial and distal mean micro-strain value was $484.5 \pm 52.1 \mu \varepsilon$.

The difference between Group I \& II was statistically significant and $\mathrm{P}$ value was $0.007 *(\mathrm{p} \leq 0.05)$.

\section{b- At the buccolingual midpoint of the mesial marginal ridge loading:}

For group I: total buccal, palatal, mesial and distal mean micro-strain value was $245.5 \pm 125.75 \mu \varepsilon$.

For group II: total buccal, palatal, mesial and distal mean micro-strain value was $611.5 \pm 298.3 \mu \varepsilon$. 
The difference between Group I \& II was statistically significant and $\mathrm{P}$ value was $0.049^{*} \quad(\mathrm{p} \leq 0.05)$.

\section{c- At the buccolingual midpoint of the distal marginal ridge loading:}

For group I: total buccal, palatal, mesial and distal mean micro-strain value was $250.5 \pm 106.4 \mu \varepsilon$.

For group II: total buccal, palatal, mesial and distal mean micro-strain value was as $443.5 \pm 137.8 \mu \varepsilon$.

The difference between Group I \& II was statistically significant and $\mathrm{P}$ value was $0.038^{*} \quad(\mathrm{p} \leq 0.05)$.

\section{d- At the Oblique $\left(45^{\circ}\right.$ inclined load) at the central fossa:}

For group I: total buccal, palatal, mesial and distal mean micro-strain value was $3359 \pm 959.4 \mu \varepsilon$.

For group II: total buccal, palatal, mesial and distal mean micro-strain value was $4552 \pm 858 \mu \varepsilon$.

The difference between Group I \& II was no statistical significance and P value was 0.072 ( $p>0.05)$.

Moreover, to compare total micro-strain values of the vertical loads at (central fossa, mesial marginal ridge and distal marginal ridge) between the two different implants studied groups, student t-test for statistical analysis was used Table (2) and Figure (4) showing that: The highest mean micro-strain value was recorded in Group II: $(513.2 \pm 108.2 \mu \varepsilon)$, while in Group I it revealed lower mean micro-strain value $(260.0 \pm 192.6 \mu \varepsilon)$.

Therefore, Group II: (implants with wide-groove threads crest module design) showed statistically significant effect on the mean micro-strain values than Group I: (implants with micro threads crest module design $)(\mathrm{p} \leq 0.05)$.

Table 2: Comparison of total micro-strain values of the vertical loads between the two different implants studied groups.

\begin{tabular}{|c|c|c|c|c|c|}
\hline \multirow{2}{*}{ Implant } & \multicolumn{4}{|c|}{ Average values of vertical loads } & \multirow{2}{*}{$t(P)$} \\
\hline & Minimum & Maximum & Mean & SD & \\
\hline$\underset{\text { I }}{\text { Group }}$ & 125.0 & 430.0 & 260.0 & 108.2 & \multirow{2}{*}{$\begin{array}{c}4.438 \\
(<0.001)^{*}\end{array}$} \\
\hline $\begin{array}{c}\text { Group } \\
\text { II }\end{array}$ & 345.0 & $1065 .($ & 513.2 & & \\
\hline
\end{tabular}

t: independent samples t-test

$* \mathrm{P} \leq 0.05$ (significant)

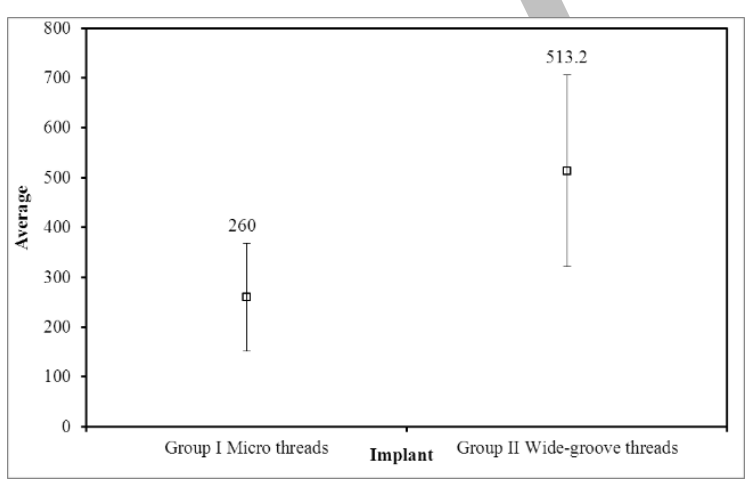

Fig. (4):Comparison of total micro-strain values of the vertical loads between the two different implants studied groups.

\section{DISCUSSION}

The present study was conducted to evaluate the influence of occlusal loading location on the strain developed around dental implants with two different crest module designs for replacing maxillary left first premolar.

A drilling guide template has been used to facilitate the implant positioning in the accurate position. A clear drilling surgical guide was fabricated to ensure implant placement within its place (22).

In this study, wax pattern crowns were fabricated using optical impression of the Sirona inLab CAD-CAM system to standardize of the entire superstructure of the two types of implants (23).

The material of the crown used in this study was Co-Cr alloy to allow even stress distribution around the implant and to be more capable to transfer the load applied (24).

Bonded electrical resistance strain gauges technology was used for the purpose of evaluation the strains that developed around the implants during the loadings. The dimension of the strain gauges used were (10 mm length, $1 \mathrm{~mm}$ width) which allowed them to be installed without interference with the prosthesis. Strain gauges were adhered to the four surfaces around the implant to monitor the stress when applying the loads; this is in agreement with Karl et at (25).

Schrotenboer J et al. studied the effect of platform switching on crestal bone stress levels and found that, platform switching reduced stress in both the groups, but to a greater degree in the microthread model compared to the macro-threaded neck model (26).

In this study, loads were applied at (the central fossa, buccolingual midpoint of the mesial marginal ridge and buccolingual midpoint of the distal marginal ridge) with vertical load parallel to the long axis of the implant then oblique ( $45^{\circ}$ inclined load) at the central fossa. It is due to that the magnitudes of the biting forces are dependent on the force directions (vertical and oblique). This was proved by Lin C-L et al who found that strains become more detrimental with oblique loading than vertical loading (27). Table (1) Figure (3).

These findings were in accordance with other studies, which stated that oblique load is associated with higher stresses $(28,29)$. It is important to emphasize that oblique load application has been related to more realistic occlusal loading (30). Comparing different loads application (vertical and oblique), it was possible to see some peculiarities in the stress distribution in different parts of the single implant system. The oblique load lead to higher stress concentration in all parts analyzed (buccal, lingual, mesial, and distal).

In this study there was no extra micro-strain developed around the implant in the same studied group when inserting loads on both marginal ridges compared to the load inserted at the central fossa. As the implants used were $(4.1 \mathrm{~mm})$ in diameter at the premolar region with $8 \mathrm{~mm}$ occlusal table width leaving up to $2 \mathrm{~mm}$ from each marginal ridge to the margin of the implant. Thus no bending moments nor cantilever effect resulted from loads applied at mesial or distal marginal ridges for both mirco and wide-groove threads crest module designs; this explained in Table (1) Figure (3).

This was in agreement with Abreu CW et al. who concluded that the offset loading did not have an influence 
on increasing the strain around an implant until it reached more than $2 \mathrm{~mm}$ away from the implant (31).

In this study two different crest module designs implants were used; micro-threads and wide-groove threads. The overall strains developed around implants of group II ( wide-groove threads crest module design) were higher than those developed around implants of group I (micro threads crest module designs) when vertical loads applied and these differences in the strains were found to be statistically significant Table (2) Figure (4).

This is because placing micro-threads on the implant neck greatly increases the surface area of the implant thus decreasing the strain around the implant (Stress $=$ Force/Area) so to reduce stress, the surface area must increase.

This was in agreement with many studies (Kang Y. et al, Ozkir SE. et al and Culhaoglu A. et al) that concluded that lower stress levels were observed around the implants with micro-threads crest module types and a small thread gives the additional advantage of increasing the axial stiffness of the implant, resulting in an additional reduction of the peak interfacial shear stress (32-34).

While, these results were against the results of Schrotenboer $\mathrm{J}$ et al, who concluded that micro-threaded implants increased bone stress at the crestal portion when compared with the macro-threaded implants (35).

\section{CONCLUSION}

Within the limitation of this study the following could be concluded:

1. Crest module designs affected the stress pattern induced around dental implants.

2. Micro threads crest module design of dental implant had a favorable effect on the stress distribution when compared with wide-groove threads crest module design dental implant.

3. Micro-strain distribution around dental implant of different types of loads was better in case of vertical loads than oblique loads.

4. Using appropriate implant diameter in relation to the edentulous space minimizes the moment (bending) stresses induced by off-axial loading on the crown restoration.

\section{CONFLICT OF INTEREST}

The authors declare that they have no conflicts of interest.

\section{ACKNOWLEDGMENT}

I would like to acknowledge Ala'a Maher, for the unwavering support throughout the thesis process.

\section{REFERENCES}

1. Branemark PI, Zarb GA, Albrektsson T. Tissueintegrated prostheses: osseointegration in clinical dentistry. Chicago: Quintessence Pub; 1985: 11-76.

2. Sousa T, Lelis V, Santos V, Nishioka G, Asconcellos L, Nishioka R. Strain Gauge analysis of non-axial loads in three-element implant supported prostheses. Braz Dent Sci. 2013; 16: 24-30.

3. Adell R, Lekholm U, Rockler B, Branemark PI. A 15year study of osseointegrated implants in the treatment of the edentulous jaw. Int J Oral Surg. 1981;10:387416.
4. Albrektsson T, Zarb G. The long-term efficiency of currently used dental implants: A review and proposed criteria of success. Int J Oral Maxillofac Implants. 1986;1:11-25.

5. Oh TJ, Yoon J, Misch CE, Wang HL. The causes of early implant bone loss: Myth or science? J Periodontol. 2002;73:322-33.

6. Misch CE. Dental Evaluation: Factors of Stress. 2nd ed. St. Louis: CV Mosby; 1999: 122-3.

7. Jung YC, Han CH, Lee KW. A 1-year radiographic evaluation of marginal bone around dental implants. Int J Oral Maxillofac Implants. 1996;11:811-8.

8. Guo E. Mechanical Properties of Cortical Bone and Cancellous Bone Tissue. 2nd ed. Boca Raton, FL: CRC Press; 2001:1-23.

9. Jovanovic SA. Diagnosis and treatment of peri implant complications. In: Newman MG, Takei HH, Carranza FA (eds). Carranza's Clinical Periodontology. 9th ed. Philadelphia: WB Saunders; 2003. pp 931-42.

10. Pilliar RM, Deporter DA, Watson PA, Valiquette N. Dental implant design-effect on bone remodeling. J Biomed Mater Res. 1991;25:467-83.

11. Ostman P, Hellman M, Albrektsson T, Sennerby L. Direct loading of Nobel Direct ${ }^{\circledR}$ and NobelPerfect ${ }^{\circledR}$ one-piece implants: A 1-year prospective clinical \& radiographic study. Clin Oral Implant Res. 2007;18:409-18.

12. Hansson S. The implant neck: Smooth or provided with retention elements. A biomechanical approach. Clin Oral Implants Res. 1999;10:394-405.

13. Ketabi M, Pilliar R, Deporter D. Factors driving periimplant crestal bone loss - literature review and discussion: Part 3. JIACD. 2010;1:66-7.

14. Baumgarten $\mathrm{H}$, Cocchetto $\mathrm{R}$, Testori $\mathrm{T}$, Meltzer A, Porter S. A new implant design for crestal bone preservation: Initial observations and case report. Pract Proced Aesthet Dent. 2005;17:735-40.

15. Assif D, Marshak B, Horowitz A. Analysis of load transfer and stress distribuition by an implantsupported fixed partial denture. J Prosthet Dent. 1996;75:285-91.

16. Clelland NL, Gilat A, McGlumphy EA, Brantley WA. A photoelastic and strain gauge analysis of angled abutments for an implant system. Int J Oral Maxillofac Implants. 1993;8:541-8.

17. Cehreli M, Duyck J, De Cooman M, Puers R, Naert I. Implant design and interface force transfer. A photoelastic and strain-gauge analysis. Clin Oral Implants Res. 2004;15:249-57.

18. Duyck J, Ronold HJ, Van Oosterwyck H, Naert I, Vander Sloten J, Ellingsen JE. The influence of static and dynamic loading on marginal bone reactions around osseointegrated implants: an animal experimental study. Clin Oral Implants Res. 2001;12:207-18.

19. Isidor F. Loss of osseointegration caused by occlusal load of oral implants. A clinical and radiographic study in monkeys. Clin Oral Implants Res. 1996;7:143-52.

20. Huang H-L, Chang Y-Y, Lin D-J, Li Y-F, Chen K-T, Hsu J-T. Initial stability and bone strain evaluation of 
the immediately loaded dental implant: an in vitro model study. Clin Oral Implants Res. 2011;22:691-8.

21. Kirkpatrick LA, Feeney BC. A simple guide to IBM SPSS statistics for version 20.0. Student ed. Belmont, Calif.: Wadsworth, Cengage Learning; 2013.

22. Vogel RC. Implant overdentures: a new standard care edentulous patients current concepts technique. Compend Contin Educ Dent. 2008;29:270-6.

23. Persson AS, Andersson M, Odén A, SandborghEnglund G. Computer aided analysis of digitized dental stone replicas by dental CAD/CAM technology. Dent Mater. 2008;24:1123-30.

24. Williams KR, Watson CJ, Murphy WM, Scott J, Gregory M, Sinobad D. Finite element analysis of fixed prostheses attached to osseointegrated implants. Quintessence Int. 1990;21:563-70.

25. Karl M, Rosch S, Graef F, Taylor T, Heckmann SM. Static implant loading caused by as-cast metal and ceramic-veneered superstructures. J Prosthet Dent. 2004;91:319-25.

26. Schrotenboer J, Tsao YP, Kinariwala V, Wang HL. Effect of microthreads and platform switching on crestal bone stress levels: A finite element analysis. J Periodontol. 2008;79:2166-72.

27. Lin C-L, Kuo Y-C, Lin A-S. Effects of dental implant length and bone quality on biomechanical responses in bone around implants: a 3-d non-linear finite element analysis. Biomed Eng-App Bas C. 2005;17:44-9.

28. Iplikçioğlu H, Akça K, Cehreli MC, Sahin S. Comparison of non-linear finite element stress analysis with in vitro strain gauge measurements on a morse taper implant. Int $\mathrm{J}$ Oral Maxillofac Implants. 2003;18:258-65.

29. Nagasawa S, Hayano K, Niino T, Yamakura K, Yoshida T, Mizoguchi T, et al. Nonlinear stress analysis of titanium implants by finite element method. Dent Mater J. 2008;27:633-9.

30. Pesqueira AA, Goiato MC, Filho HG, Monteiro DR, Santos DM, Haddad MF, et al. Use of stress analysis methods to evaluate the biomechanics of oral rehabilitation with implants. J Oral Implantol. 2014;40:217-28.

31. Abreu CW, Nishioka RS, Balducci I, Consani RL. Straight and offset implant placement under axial and nonaxial loads in implant-supported prostheses: strain gauge analysis. Prosthodont. 2012;21:535-9.

32. Kang Y-I, Lee D-W, Park K-H, Moon I-S. Effect of thread size on the implant neck area: preliminary results at 1 year of function. Clin Oral Implants Res. 2012;23:1147-51.

33. Ozkir SE, Terzioglu H. Macro design effects on stress distribution around implants: A photoelastic stress analysis. Indian J Dent Res. 2012;23:603-7.

34. Culhaoglu A, Ozkir SE, Celik G, Terzioglu H. Comparison of two different restoration materials and two different implant designs of implant-supported fixed cantilevered prostheses: A 3D finite element analysis. Eur J Gen Dent. 2013;2:114-50.

35. Schrotenboer J, Tsao YP, Kinariwala V, Wang HL. Effect of microthreads and platform switching on crestal bone stress levels: A finite element analysis. J Periodontol. 2008;79:2166-72. 